\title{
Do High Levels of Analyst Following Improve Companies' Credit Ratings: Evidence from MENA Region?
}

\begin{abstract}
Harit Satt
School of Business Administration, Al Akhawayn University in Ifrane, Morocco

Correspondence should be addressed to: Harit Satt; h.satt@aui.ma

Received date: 14 December 2015; Accepted date: 7 January 2016; published date: 30 June 2016

Academic Editor: Khalifa Ahsina

Copyright (C) 2016. Harit Satt. Distributed under Creative Commons CC-BY 4.0

Abstract

All investors and stakeholders in general worry about the accuracy of both the financial information and the corporate governance, yet at different scales. Knowing that inadequacies exist in the financial information, would we be able to find some ways that would help us improve the credit rating of the firms? In order to answer this question, our research's aim is to define the impact of analyst following (analyst quest) on firm's credit rating. The research' results exhibit that the level of analyst following has a positive influence on firms' credit rating. However, this constructive influence occurs only when there is a significant degree of analyst following. Consequently, we end up concluding that a high degree of analyst following makes it difficult for insiders to miscommunicate the right information related to firm's value which reduces agency problems leading to a positive credit rating, thus a low cost of debt.
\end{abstract}

Keywords: Analyst Following; Corporate Governance; Credit Rating

JEL classification: G32

\section{Introduction}

For the stock market to function efficiently, it needs accurate information. Once the appropriate information concerning the firms is merged with the prices, the securities are fairly priced. In fact, financial analysts work on highlighting new information related to the firm which will help them in this process. The investment decisions are usually taken by the stock market participants using the research reports of analysts, their projections, and recommendations as precise information, Lang et al. (2004). Jensen and Meckling (1976) propose that financial analysts, regarded as information intermediaries, have the ability to lessen the agency problems that firms are facing. The market value of an enterprise is a growing function of the width of investor attentiveness as Merton (1987) claims. In order to raise the

Cite this Article as: Harit Satt (2016)," Do High Levels of Analyst Following Improve Companies' Credit Ratings: Evidence from MENA Region?" Journal of Financial Studies \& Research, Vol. 2016 (2016), Article ID 924023, DOI: $10.5171 / 2016.924023$ 
responsiveness of an investor concerning a company, conventional wisdom recommends one technique to realize this which is boosting the degree of analyst following. Chung and Jo (1996) assert that the value of a business is a positive function of the number of analysts following a company. Moreover, analyst following can have an impact on the company's valuation by dropping information asymmetries and agency problems. The main objective of those analysts is to find out the information that a company wants to hide so that they guarantee that all the information is accessible to the participants in the stock market. Consequently, they influence the firm's valuation in a positive way and decrease the asymmetry of the information, thus we believe that the influence on the cost of debt will be favorable. Additionally, the higher the performance of analyst following, the higher the information found out. Hence, the extent of analyst following ought to be a significant factor of relationship between the company's valuation and the analyst following, Farooq and Satt (2014).

Through this paper, we are willing to outspread the elements referred to above by verifying if the analyst following boosts the credit rating of a business, which is an essential representation of the evaluation of the company in MENA context. As far as we know, this is the first trial that aims to bind between the two variable, Farooq and Satt (2014) already demonstrated that analysts following can boost firm performance; therefore, we can say that this paper is an extension to our previous work in order to see what if the analysts' following can go to the extent of not only positive firm performance but also the an improved credit rating. Knowing that analysts are able to expose new information, it is spontaneous to claim that they have the ability to diminish the information asymmetries between foreigners and insiders, Farooq and Satt (2014). Declining the information asymmetries leads to an expensive expropriation skill as well as penalizing managers by decreasing the problems of agency. Thus, analyst following is the most important element that can determine the performance of a company. Moreover, the higher the extent of analyst following, the lower is the information asymmetry as recommended by the conventional wisdom. Consequently, the credit rating should be better when the magnitude of analyst following is higher. According to our fallouts, we can claim that analyst following influences positively the credit rating between the year of 2002 and 2014 . Nevertheless, only high quality analyst following results in this positive influence. When lower quality analyst following is involved, we report a negative influence on firm's credit rating- an unforeseen finding. Our outcomes are partially dependent on previous literature that takes into consideration any technique that helps in resolving information asymmetries between insiders and foreigners as appropriate value for the participants in the stock market. Our results determine that the low level of analyst following affects the firm's credit rating in a negative way. This is astonishing for the reason that, at most, low analyst following should not influence the firm's cost of debt. The association between the two in a negative way is counter intuitive.

The negative association between the cost of debt and the earnings per share is another surprising result of our analysis. Within various sub-samples, this association is vigorous. The low information content of reported earnings is the reason for this negative influence. Because the investors are conscious of the misreport information of the firms in the developing markets, they have little faith on reported information, hence, discounting earnings per share. Furthermore, our paper analyzes the effect of analyst following on the reported information related to earnings in order to determine if the extent of analyst following increases the reported earnings information. Indeed, our analysis' results exhibit that it is true that analyst following increases the reported information concerning earnings, but it does not succeed entirely in strengthening the faith that investors have regarding the reported information. While the size of analyst following goes up, the extent of the negative connection between the 
performance of the firm and earnings per share decrease pointedly as confirmed by our research's results.

Our results are essential for creditors. The major difficulty these creditors are facing is their inability to differentiate between good firms and bad ones. Though, according to our results, these creditors may use analyst following to identify which company has the possibility and the ability to be solvent, conversely, which company may not be. Moreover, the analyst following, based on our results, can be used to ameliorate the informativeness of reported earnings. Furthermore, our results confirm that in order to differentiate between real and manipulated accounting information, creditors with analyst following can round off accounting information. It is imperative to indicate here that our paper enhances the debate on the efficiency of alternate/external governance mechanisms. On the other hand, our analysis' results show that analysts have some value regarding the stock market participants because they provide an augmented analysis that aids in decreasing information asymmetries, hence, ameliorating the firm's credit rating.

The remnant of the paper will include the following: Section 2 briefly discusses motivation and background for this study. Section 3 summarizes the data and Section 4 encounters valuation of our hypothesis. Section 5 discusses implications of our findings and the paper concludes with Section 6.

Information is the significant point to efficient functioning of the stock markets. Securities get priced correctly when pertinent information about companies get merged into the prices. Financial analysts play an essential role in this process by carrying out new information about companies. These analysts are capable to decrease agency problems within the company Jensen and Meckling (1976). Merton (1987) claims that the market value of a firm is an increasing function of the breadth of investor awareness.

Satt (2015) stated that when a company is perceived to be highly performing in "the eyes" of the financial analyst, the risk of default is very low, so the more the company is performing the better will be the its credit quality, hence higher the quality credit terms. It is also found that when the overall market believes in the good performance of a company, this latter will have the pressure to keep its positive performance.

This chapter highlights the idea that analyst following is a value that strengthens emerging markets' mechanisms given that financial analysts play a huge role in resolving some of the corporate governance mechanisms. Providing recent information to the participants of stock market helps analysts decide on the ineffectiveness governance mechanisms. According to Michaely and Womack (1999), analysts are defined as the agents who gather, clarify, and provide stock market participants with both public and private information. Analysts are able to determine information asymmetries by spreading precious information to creditors. Moreover, Amir et al. (1999) proposes that the research of analysts alleviate information insufficiencies that reside in financial statements. This paper discusses the role that analysis play as information providers is very significant (Claessens et al., 2002; Lins, 2003; Dyck and Zingales, 2004; Nenova, 2003). Nenova (2003) claims that firms with information asymmetries described as very high are discounted by creditors. Information asymmetries expose creditors to extreme risk and initiate agency problems within firms. Consequently, any mechanism that will contribute to the lessening of information asymmetries is of major significance to any stock market participant.

In fact, our arguments go in the same flow as the past literature arguments confirming that financial analysts can play the role of an enhancing mechanism for corporate governance in emerging markets, Farooq and Satt (2014). Analysts' substitution effect is portrayed in Lang et al. (2004) documentation. They illustrate the degree of analyst following that mitigates the unpleasant effect of lower creditors' protection on valuation. In the same 
context, Knyazeva (2007) claims that by substituting for corporate governance, analyst following enhances a firm performance. The major argument that is provided here states that analysts' position as information providers gives creditors the possibility to balance all the misrepresented information by the firm. Conventional wisdom argues that the higher the number of analysts digging for information, the larger are the chances that information is rightly reported and disclosed. As a matter of fact, lower analyst following should influence firm's credit rating less than higher analyst following. Hence, information asymmetries are not resolved to the point that creditors start valuing analyst following. We can come to the conclusion that information asymmetries draw a constructive but a nonlinear relationship between firms' cost of debt and analyst following.

\section{Analysts' following and the Cost of Debt}

Many characteristics are supposed to influence the company's cost debt, we suspect that analysts' following is one of the important variables that affect the cost of debt. Giving numerous factors (refer to table 1 for more information about these factors), HIGH analysts' following refers to the level of analysts following that is above the average; and LOW analysts following refers to the level of analysts following that is below the average. Results revealed that when there is a rise in the score, there is a decline in the cost of debt.

Table 1: Variables Description and Sources

\begin{tabular}{|c|c|c|}
\hline Variable & Description & Source \\
\hline Bonds Ratings & $\begin{array}{l}\text { Appendix A provides detailed information about this ordinal } \\
\text { variable. The bond ratings that are used by S\&P are changed to } \\
\text { a range from } 1 \text { to } 7 \text { where } 1 \text { represents the lowest rating and } 7 \\
\text { the highest rating. Bond rating depends on the company bonds } \\
\text { portfolio. }\end{array}$ & F-Database \\
\hline $\begin{array}{l}\text { High Analysts' } \\
\text { Following }\end{array}$ & $\begin{array}{l}\text { Analysts following is the number of analysts following a firm } \\
\text { at a given point of time. High Analysts' following is a dummy } \\
\text { variable that is given the value } 1 \text { if the level of analysts } \\
\text { following is above the mean; otherwise, value of } 0 \text { is assigned }\end{array}$ & W-S Database \\
\hline $\begin{array}{l}\text { Company } \\
\text { Profitability }\end{array}$ & $\begin{array}{l}\text { A variable that calculates the profitability of the company by } \\
\text { dividing its net income by its total assets. }\end{array}$ & W-S Database \\
\hline Company Size & The company size is calculated by its total assets in dollars. & W-S Database \\
\hline Company risk & $\begin{array}{l}\text { The company's risk is calculated by the standard deviation of } \\
\text { the net income of every company in the sample. }\end{array}$ & W-S Database \\
\hline Bonds Maturity & $\begin{array}{l}\text { A variable that calculates the log maturity in years. The } \\
\text { weights are measured by the size of the issuance of the } \\
\text { maturity class to the total size of the issuance for a given year. } \\
\text { Then, the weights are multiplied by the respective maturity } \\
\text { and added to get the bonds weighted average maturity. }\end{array}$ & W-S Database \\
\hline Convertible & A dummy variable that gives the value 1 to companies with & W-S Database \\
\hline
\end{tabular}




\begin{tabular}{|c|c|c|}
\hline Provisions & $\begin{array}{l}\text { convertible provisions and } 0 \text { to companies with no convertible } \\
\text { provisions. These provisions let the bondholder change his or } \\
\text { her bonds to shares. }\end{array}$ & \\
\hline Issue Size & A variable that represents the size of the issuance. & W-S Database \\
\hline Leverage & $\begin{array}{l}\text { A variable that represents the influence of the company; } \\
\text { calculated by dividing the company debts by its equity. }\end{array}$ & W-S Database \\
\hline Creditors Rights & $\begin{array}{l}\text { This variable is an index that ranges from } 0 \text { to } 4 \text {. When a } \\
\text { country enforces restrictions in favor of creditors, } 1 \text { is added } \\
\text { to its score. When the secured creditors make sure they get } \\
\text { their investment back, the score changes to } 2 \text {. When the } \\
\text { secured creditors are the first to collect their money in case of } \\
\text { bankruptcy, the score changes to } 3 \text {. At the end, when the } \\
\text { secured creditors do not wait for the problems to get resolved } \\
\text { in order to get their money back, the score changes } 4 \text {. }\end{array}$ & $\begin{array}{l}\text { Djankov et al. } \\
\qquad(2005)\end{array}$ \\
\hline Public Registry & $\begin{array}{l}\text { Public registry is a database developed by public authorities. } \\
\text { This database contains all the debt profiles of borrowers in the } \\
\text { economy. The assembled information is available to all } \\
\text { financial institutions. The variable is given the value } 1 \text { if the } \\
\text { country has a public registry and } 0 \text { if otherwise. }\end{array}$ & $\begin{array}{l}\text { Djankov et al. } \\
\text { (2005) }\end{array}$ \\
\hline $\begin{array}{l}\text { Efficiency of } \\
\text { Bankruptcy } \\
\text { Process }\end{array}$ & $\begin{array}{l}\text { When a company exposes itself to bankruptcy costs, theses } \\
\text { costs are subtracted from the company's terminal value, which } \\
\text { is discounted to find the present value. The greater the value, } \\
\text { the better the company. }\end{array}$ & $\begin{array}{l}\text { Djankov et al. } \\
\qquad(2007)\end{array}$ \\
\hline News Circulation & Daily newspapers sold, which is divided by the population. & $\begin{array}{l}\text { Dyck and Zingales } \\
(2004)\end{array}$ \\
\hline Manufacturing & $\begin{array}{l}\text { Dummy variable that equals } 1 \text { if the company functions in the } \\
\text { Manufacturing industry and } 0 \text { if otherwise. }\end{array}$ & \\
\hline Trades & $\begin{array}{l}\text { Dummy variable that equals } 1 \text { if the company functions in the } \\
\text { Trades industry and } 0 \text { if otherwise. }\end{array}$ & \\
\hline Finance & $\begin{array}{l}\text { Dummy variable that equals } 1 \text { if the company functions in the } \\
\text { Finance industry and } 0 \text { if otherwise. }\end{array}$ & \\
\hline Utility & $\begin{array}{l}\text { Dummy variable that equals } 1 \text { if the company functions in the } \\
\text { Utility industry and } 0 \text { if otherwise. }\end{array}$ & \\
\hline
\end{tabular}

We have the following hypothesis:

H1: High level of analyst following will lower the company's cost of debt financing.
H2: High level of analyst following leads to higher bonds ratings.

The study we are conducting is going to bring more value since the existing one is 
very limited. The first goal is to evaluate the perception of the corporate bond market of the quality of the company's performance and analysts following in the market. The second objective, the study we are making is not the same as Jenzazi (2010) and the other studies because it will stress on the MENA framework when it comes to this issue. That is to say that not only we will have a better understanding of the functioning of the different debt markets around the world, but this will enable us to perceive in which way the external governance mechanisms (such as the legal and extra-legal institutions) relate to the semi-internal mechanisms (in our case analysts' following) in order to improve the entire governance quality in one country.

\section{Methodology and Descriptive Statistics}

\section{Specifications}

The purpose of the research is to determine the relationship between analysts' following $\mathrm{s}$ and bonds' ratings. The following general specification will be used for this purpose.

Bond Rating $=\mathrm{f}$ (Analysts' following, Issuer Characteristics, Issue Characteristics)

The determinants used to make the study are the three following: Analysts' following, Issuer Characteristics, Issue Characteristics. Issue Characteristics variable refers to the profitability of the company computed using the company's return on assets, the company size which measured by the company total assets, the company risk that is measured by the company variability of earnings, and the leverage that is measured by the debt to equity ratio. This variable is composed of issue size or the size of the bonds, the bonds maturity, and the convertible provision (an option enabling a bondholder to exchange the bonds for shares).
The rating bonds used are from seven distinct ordering categories (exemplified by the S\&P ratings). The last statement signifies that since the bond rating is an ordinal variable, we can use the Ordered Probit Model.

\section{Data Sources and Variables}

Our sample is made of 600 companies selected from Mena Region. Table 2 represents the description of this sample between year 2002 and 2014. The ratings bonds used have a range from AAA to D, taken from S\&P credit rating and they represent companies' credit worthiness. This enable to distinct between the companies that can repay back their loans at due dates and those who cannot. Appendix reveals that the proposed ratings obtained from S\&P have been converted to ordering numbers ranging from 1 to 7,1 representing the lowest rating and 7 the highest one. To convert the ratings we used the research that was conducted by Ashbaugh, Collins, and LaFond (2006). The data of bonds ratings were obtained from F- Database.

This paper emphasizes in which way the extent of analyst quest impacts the performance of a company in the MENA region. A similar study was conducted by Satt(2015) that opted to clarify the relationship between analysts' recommendations and their impact on credit rating; however, when it comes to analysts' following, this is the very first attempt to test for it and include it in such a context.

The following table documents the descriptive statistics for analyst following in the MENA region. The sample period is from 2002 to 2014. Panel A document descriptive statistics for each year, while Panel B and Panel C document similar statistics for each country and each industry respectively. 
Table 2.1: Descriptive statistics for analyst following

Panel A: Analyst following in different years

\begin{tabular}{|c|c|c|c|c|}
\hline Years & Average & $\begin{array}{c}\text { Standard } \\
\text { Deviation }\end{array}$ & Maximum & Minimum \\
\hline $\mathbf{2 0 0 2}$ & 0.3233 & 1.1791 & 13 & 0 \\
\hline $\mathbf{2 0 0 3}$ & 0.6909 & 1.4454 & 13 & 0 \\
\hline $\mathbf{2 0 0 4}$ & 0.2621 & 0.8497 & 15 & 0 \\
\hline $\mathbf{2 0 0 5}$ & 0.4681 & 1.1791 & 14 & 0 \\
\hline $\mathbf{2 0 0 6}$ & 0.3454 & 1.6577 & 18 & 0 \\
\hline $\mathbf{2 0 0 7}$ & 1.4344 & 2.1206 & 19 & 0 \\
\hline $\mathbf{2 0 0 8}$ & 1.4015 & 2.8732 & 22 & 0 \\
\hline $\mathbf{2 0 0 9}$ & 0.2621 & 0.5444 & 21 & 0 \\
\hline $\mathbf{2 0 1 0}$ & 0.2456 & 1.1791 & 21 & 0 \\
\hline $\mathbf{2 0 1 1}$ & 0.344 & 1.4454 & 21 & 0 \\
\hline $\mathbf{2 0 1 2}$ & 1.0439 & 2.1206 & 22 & 0 \\
\hline $\mathbf{2 0 1 3}$ & 1.4534 & 2.8732 & 23 & 0 \\
\hline $\mathbf{2 0 1 4}$ & 1.5430 & 2.8732 & 26 & 0 \\
\hline
\end{tabular}

Panel B: Analyst following in different countries

\begin{tabular}{|c|c|c|c|c|}
\hline Country & Average & Standard Deviation & Maximum & Minimum \\
\hline Algeria & 0.3095 & 0.6220 & 3 & 0 \\
\hline Bahrain & 1.3145 & 2.3932 & 14 & 0 \\
\hline Egypt & 0.3102 & 0.7532 & 8 & 0 \\
\hline Iran & 0.2415 & 0.9515 & 8 & 0 \\
\hline Iraq & 1.6238 & 1.1392 & 6 & 0 \\
\hline Jordan & 0.6487 & 1.8132 & 15 & 0 \\
\hline Kuwait & 0.6352 & 1.6066 & 23 & 0 \\
\hline Lebanon & 1.6780 & 3.2715 & 12 & 0 \\
\hline Yemen & 0.3095 & 0.6220 & 3 & 0 \\
\hline $\begin{array}{l}\text { United Arab } \\
\text { Emirates }\end{array}$ & 1.3145 & 2.3932 & 33 & 0 \\
\hline Libya & 0.3102 & 0.7562 & 4 & 0 \\
\hline Morocco & 0.2415 & 0.9515 & 12 & 0 \\
\hline Oman & 1.6268 & 1.1692 & 14 & 0 \\
\hline Azerbaijan & 0.6487 & 1.8162 & 12 & 0 \\
\hline Sudan & 0.6652 & 1.6066 & 2 & 0 \\
\hline Qatar & 1.6780 & 6.2715 & 34 & 0 \\
\hline $\begin{array}{c}\text { Saudi } \\
\text { Arabia } \\
\end{array}$ & 0.6095 & 0.6220 & 23 & 0 \\
\hline Syria & 1.6145 & 2.6962 & 3 & 0 \\
\hline Tunisia & 0.6102 & 0.7562 & 5 & 0 \\
\hline
\end{tabular}




\begin{tabular}{|l|c|c|c|c|}
\hline Country & Average & Standard Deviation & Maximum & Minimum \\
\hline Turkey & 0.2415 & 0.9515 & 12 & 0 \\
\hline Mauritania & 1.6238 & 1.1392 & 8 & 0 \\
\hline Cyprus & 0.6487 & 1.8132 & 6 & 0 \\
\hline Georgia & 0.6352 & 1.6066 & 5 & 0 \\
\hline
\end{tabular}

Panel C: Analyst following in different industries

\begin{tabular}{|l|c|c|c|c|}
\hline Industry & Average & $\begin{array}{c}\text { Standard } \\
\text { Deviation }\end{array}$ & Maximum & Minimum \\
\hline Oil and Gas & 0.3647 & 0.9238 & 5 & 0 \\
\hline Basic Materials & 0.9000 & 1.5137 & 10 & 0 \\
\hline Industrials & 0.7870 & 1.6066 & 14 & 0 \\
\hline Consumer Goods & 0.4603 & 0.9242 & 5 & 0 \\
\hline Healthcare & 0.6000 & 0.8329 & 3 & 0 \\
\hline Consumer Services & 0.4240 & 1.4241 & 15 & 0 \\
\hline Telecommunication & 4.7600 & 4.6319 & 14 & 0 \\
\hline Utilities & 1.6285 & 1.7836 & 6 & 0 \\
\hline Financials & 0.7851 & 1.9637 & 20 & 0 \\
\hline Technology & 1.1428 & 2.3904 & 11 & 0 \\
\hline
\end{tabular}

\section{Analyst following}

Analyst following can be defined as the highest number of analysts that deliver annual earnings forecasts in a specific year. In fact, when there are a high number of analysts following a company, it leads to a better information environment and a small information asymmetry. We obtain the statistics concerning the analyst following from the I/B/E/S. Table 2 provides the descriptive statistics related to the analyst following throughout our sample period. The three panels provide descriptive statistics: panel A delivers the statistics corresponding to each year, meanwhile the two other panels $B$ and $C$ supply same data corresponding to each country and industry respectively. Based on the data from Table 2, Panel A, we notice that average analyst following went up from 0.32 to 1.54 between 2002 and 2014. Moreover, the data given exhibits a regular enhancement in analyst industry in the MENA region. Furthermore, it reveals that, in 2002, 13 analysts is the maximum of analyst following that a company can produce, but this number went up in 2014 to reach 26 analysts. On the other hand, Table 2, Panel B, determines that Qatar reaches the highest level of analyst following in the region, and firms headquartered in United Arab Emirates,

Morocco. United Arab Emirates, Morocco, and Egypt have an average analyst following of 1.6780, 1.6238, and 1.3145 respectively. Besides, Table 2, Panel B, shows that companies that headquartered in Iran and Turkey have the least level of analyst following compared to other firms in the region. On the other hand, telecommunication's firms are characterized by having the highest number of analyst following as shown in Table 2, Panel $\mathrm{C}$. This result is obvious since most of the firms working in the sector of telecommunication have a large size and are very lucrative in the region. 
Panel C: Analyst following in different industries

\begin{tabular}{|l|c|c|c|c|}
\hline Industry & Average & $\begin{array}{c}\text { Standard } \\
\text { Deviation }\end{array}$ & Maximum & Minimum \\
\hline Oil and Gas & 0.3647 & 0.9238 & 5 & 0 \\
\hline Basic Materials & 0.9000 & 1.5137 & 10 & 0 \\
\hline Industrials & 0.7870 & 1.6066 & 14 & 0 \\
\hline Consumer Goods & 0.4603 & 0.9242 & 5 & 0 \\
\hline Healthcare & 0.6000 & 0.8329 & 3 & 0 \\
\hline Consumer Services & 0.4240 & 1.4241 & 15 & 0 \\
\hline Telecommunication & 4.7600 & 4.6319 & 14 & 0 \\
\hline Utilities & 1.6285 & 1.7836 & 6 & 0 \\
\hline Financials & 0.7851 & 1.9637 & 20 & 0 \\
\hline Technology & 1.1428 & 2.3904 & 11 & 0 \\
\hline
\end{tabular}

The value of 1 is assigned to the dummy variable that is the analyst average recommendations if it is positive (buy or strong buy) and 0 otherwise.

To provide more explanation on the bonds ratings, two control variables were added to the model, which are the issue and issuer variables. More details on these variables are given in Table 1 . The control variables data were obtained from W.S Database.

Following the research papers of Satt (2015), Anderson, Mansi and Reeb (2003) and Boukhari and Ghouma (2008), the calculation of the bonds ratings, the convertible provision, and the issue size (the issue characteristics) was done on a portfolio approach. We compiled the whole company issues for each year, and the size of the issue to the entire issues represented the weight used in the calculation of the average bonds ratings, the convertible provision, and the issue size associated with each company over every year of the duration of our study.

The formula of the bond rating can be presented as thus:

Prob. $($ Bonds Ratings $=X)=F\left(b_{1}\right.$. Analysts' Following $+b_{2}$. Company

Profitability $+b_{3}$. Company Size $+b_{4}$. Company Risk $+b_{5}$. Bonds

Maturity $+b_{6}$. Convertible Provisions $+b_{7}$. Issue Size $+b_{8}$. Leverage

+ Institutional variables + Year Dummies+ Industry Dummies + ei);

Where $X$ belongs to $\{1,2,3,4,5,6,7\}$

\section{Empirical Results}

Panel (A), table 3 stands for the descriptive statistics connected to the variables used in our study, which begins with the credit rating variable with a mean equal to 4.432 and that signifies an S\&P rating of $\mathrm{BBB}+$. 
Table 3 Panel A: Analyst following in different years

\begin{tabular}{|c|c|c|c|c|}
\hline Years & Average & $\begin{array}{c}\text { Standard } \\
\text { Deviation }\end{array}$ & Maximum & Minimum \\
\hline $\mathbf{2 0 0 2}$ & 0.3233 & 1.1791 & 13 & 0 \\
\hline $\mathbf{2 0 0 3}$ & 0.6909 & 1.4454 & 13 & 0 \\
\hline $\mathbf{2 0 0 4}$ & 0.2621 & 0.8497 & 15 & 0 \\
\hline $\mathbf{2 0 0 5}$ & 0.4681 & 1.1791 & 14 & 0 \\
\hline $\mathbf{2 0 0 6}$ & 0.3454 & 1.6577 & 18 & 0 \\
\hline $\mathbf{2 0 0 7}$ & 1.4344 & 2.1206 & 19 & 0 \\
\hline $\mathbf{2 0 0 8}$ & 1.4015 & 2.8732 & 22 & 0 \\
\hline $\mathbf{2 0 0 9}$ & 0.2621 & 0.5444 & 21 & 0 \\
\hline $\mathbf{2 0 1 0}$ & 0.2456 & 1.1791 & 21 & 0 \\
\hline $\mathbf{2 0 1 1}$ & 0.344 & 1.4454 & 21 & 0 \\
\hline $\mathbf{2 0 1 2}$ & 1.0439 & 2.1206 & 22 & 0 \\
\hline $\mathbf{2 0 1 3}$ & 1.4534 & 2.8732 & 23 & 0 \\
\hline $\mathbf{2 0 1 4}$ & 1.5430 & 2.8732 & 26 & 0 \\
\hline
\end{tabular}

The first variable in the issuer characteristics variables stands for analysts' recommendations with a mean equal to 0.71 . This signifies that about $71 \%$ of the companies of the sample are having positive recommendations - a result that confirms what Jegadeesh et al. (2004) presented, claiming that most of analysts' recommendations are close to "buy" recommendations, which is the same phenomenon as discussed by Satt (2015). The average mean for the return on assets regarding the profitability of the company is 5.32. 88 million dollars, which was calculated by averaging the total assets of the 600 companies in the sample, represent the mean of the company size. 4.43 years represents the mean average for the bonds maturity based on the issuance variables. The second variable, represented by the convertible bonds option, has a mean equal to $5.6 \%$, meaning that $5.6 \%$ of the companies offered this option to their bondholders.

Panel (B1) from table 3 shows the correlation between the bond rating taken as the dependent variable and the other independent variables that, which the analysts' are following, the issue characteristics variables, and the issuer characteristics. Consequently, there is a strong relationship between the dependent variable and the various other independent variables.

The analysts' recommendation, the company performance, the company size, and the convertible option are really connected to the dependent variable at important levels of less than 1 percent.

In addition, it was revealed that the company leverage is interconnected positively at a significant level of 5 percent. Nevertheless, only one variable that is replaced by Bonds maturity was found to be negatively related to the Bond Ratings at an important level of less than $1 \%$. On the other hand, it was discovered that there is no significant association between the two variables, the issue size and the company and the bonds ratings. 
Table 3 Panel B: Analyst following in different countries

\begin{tabular}{|c|c|c|c|c|}
\hline Country & Average & Standard I & Maximum & Minimum \\
\hline Algeria & 0.3095 & 0.6220 & 3 & 0 \\
\hline Bahrain & 1.3145 & 2.3932 & 14 & 0 \\
\hline Egypt & 0.3102 & 0.7532 & 8 & 0 \\
\hline Iran & 0.2415 & 0.9515 & 8 & 0 \\
\hline Iraq & 1.6238 & 1.1392 & 6 & 0 \\
\hline Jordan & 0.6487 & 1.8132 & 15 & 0 \\
\hline Kuwait & 0.6352 & 1.6066 & 23 & 0 \\
\hline Lebanon & 1.6780 & 3.2715 & 12 & 0 \\
\hline Yemen & 0.3095 & 0.6220 & 3 & 0 \\
\hline $\begin{array}{l}\text { United Arab } \\
\text { Emirates }\end{array}$ & 1.3145 & 2.3932 & 33 & 0 \\
\hline Libya & 0.3102 & 0.7562 & 4 & 0 \\
\hline Morocco & 0.2415 & 0.9515 & 12 & 0 \\
\hline Oman & 1.6268 & 1.1692 & 14 & 0 \\
\hline Azerbaijan & 0.6487 & 1.8162 & 12 & 0 \\
\hline Sudan & 0.6652 & 1.6066 & 2 & 0 \\
\hline Qatar & 1.6780 & 6.2715 & 34 & 0 \\
\hline $\begin{array}{c}\text { Saudi } \\
\text { Arabia } \\
\end{array}$ & 0.6095 & 0.6220 & 23 & 0 \\
\hline Syria & 1.6145 & 2.6962 & 3 & 0 \\
\hline Tunisia & 0.6102 & 0.7562 & 5 & 0 \\
\hline Turkey & 0.2415 & 0.9515 & 12 & 0 \\
\hline Mauritania & 1.6238 & 1.1392 & 8 & 0 \\
\hline Cyprus & 0.6487 & 1.8132 & 6 & 0 \\
\hline Georgia & 0.6352 & 1.6066 & 5 & 0 \\
\hline
\end{tabular}

To verify the first hypothesis, a mean comparison tests was carried out and the sample was separated into sub groups. The first one stands for companies with High level of analysts' following and the second for the remaining. A T-test confirms the hypothesis, knowing that the first group's mean has a higher value (5.2) compared with the second group's mean (3.1). Moreover, both the T-Test and the
Wilcoxon-Mann-Whitney test support the difference between the two means that is considerably different from zero $(5 \%$ significance level).

This information indicates that this company is one of those with high level of analysts' following that profits from higher credit ratings. 
Table 3 Panel C: Analyst following in different industries

\begin{tabular}{|l|c|c|c|c|}
\hline Industry & Average & $\begin{array}{c}\text { Standard } \\
\text { Deviation }\end{array}$ & Maximum & Minimum \\
\hline Oil and Gas & 0.3647 & 0.9238 & 5 & 0 \\
\hline Basic Materials & 0.9000 & 1.5137 & 10 & 0 \\
\hline Industrials & 0.7870 & 1.6066 & 14 & 0 \\
\hline Consumer Goods & 0.4603 & 0.9242 & 5 & 0 \\
\hline Healthcare & 0.6000 & 0.8329 & 3 & 0 \\
\hline Consumer Services & 0.4240 & 1.4241 & 15 & 0 \\
\hline Telecommunication & 4.7600 & 4.6319 & 14 & 0 \\
\hline Utilities & 1.6285 & 1.7836 & 6 & 0 \\
\hline Financials & 0.7851 & 1.9637 & 20 & 0 \\
\hline Technology & 1.1428 & 2.3904 & 11 & 0 \\
\hline
\end{tabular}

Panel A from Table 4 stands for the results of the ordered Probit estimation on bonds rating. These results are the same as those we expected from the study. The results clearly show that there is a positive connection between bonds ratings and analysts' following with +0.7 at a significance level of $5 \%$. Thus, this corroborates the first hypothesis made about the study saying that there is a positive correlation between analysts' following and bonds ratings. Both the company's profitability and size have positive impact on the bonds ratings. Nevertheless, regarding the convertible bonds option, it is the only variable that is capable of having a meaningful impact on companies' bonds ratings. On the other hand, no major effect on the bonds ratings is caused by the other issue and issuer variables.

Table 4: The Effect of High levels of analysts' following on Bond ratings

\begin{tabular}{|l|c|l|}
\hline $\begin{array}{l}\text { Dependent Variable } \\
\text { Bonds ratings }\end{array}$ & $\begin{array}{c}\text { Expected } \\
\text { Sign }\end{array}$ & \multicolumn{1}{c|}{ Model } \\
\hline Average Analysts' following & + & $0.0231(0.0033)^{* *}$ \\
\hline Company Profitability & + & $0.0233(0.0000)^{* * *}$ \\
\hline Company Size (in billions of U.S Dollars) & + & $98.6(0.0001)^{* * *}$ \\
\hline Company risk (in millions of U.S Dollars) & - & $-335(0.678)$ \\
\hline Bonds Maturity & - & $-0.577(0.063)^{*}$ \\
\hline Convertible Provisions & + & $0.787(0.0001)^{* * *}$ \\
\hline Issue Size & - & $3.23 \times 10(0.0223)$ \\
\hline Leverage & - & $-0.0001(0.323)$ \\
\hline Creditors Rights & + & $0.533(0.0000)^{* * *}$ \\
\hline Public Registry & + & $1.222(0.0000)^{* * *}$ \\
\hline Bankruptcy Efficiency & + & $0.0353(0.0000)^{* * *}$ \\
\hline News Circulation & + & $0.2333(0.0000)^{* * *}$ \\
\hline Manufacturing & & $0.775(0.569)$ \\
\hline Trades & & $-0.0232(0.998)$ \\
\hline Finance & & $0.122(0.0000)^{* * *}$ \\
\hline Utility & & $0.233(0.0001)^{* * *}$ \\
\hline N & & 600 \\
\hline Pseudo R ${ }^{2}$ & & $19.37 \%$ \\
\hline LR - Chi ${ }^{2}$ & & 322.35 \\
\hline Significance & $0.0000)^{* * *}$ \\
\hline
\end{tabular}

The study confirmed that there is a significant positive link between analysts' following and bonds ratings in MENA region, as we can see in the table above, analysts' following's coefficient is very significant and positive. A company that 
could generate a high level of analysts following will directly experience higher rating bonds. This further explains that the costs of debt, in the form of bonds, are decreased as a result of creditors asking for lower premium to lend their money.

\section{Limitations}

One major drawback was noticed about the sample selected. In point of fact, FDatabase and W-Database gave us the bonds ratings data and recommendations' data, respectively. These two databases allowed us to assemble 600 observations that followed the distribution presented in Table 2. In fact, this statement could have influenced our sample representativeness.

\section{Conclusion}

The study carried out in this paper seeks to show that there is a positive connection between analysts' following and the bonds rating. For this reason, a sample of 600 companies selected from MENA region was used. The sample data is from 2002 to 2014, a period of 12 years. Our expectations agree with the results of the Ordered Probit regression. Consequently, a company that's able to produce a high level of analysts' following is able to have higher bonds rating. In other words, a company with good performance is one with high level of bonds ratings and this has an effect on the debt cost by reducing it. Bearing in mind that there are no previous studies carried out to explain the purpose discussed in our paper, this research done will bring more value on this, even in the developing markets context. When the firm is being followed by a high number of analysts, it gives a favorable signal about the company's corporate governance, because high level of analysts' following can be translated to a large number of specialists that are zooming on the company and every single action conducted by its management will be communicated widely to the market, even in less efficient markets, Satt (2015). Therefore, high levels of analysts following, reduces the fear of creditors and assures them that if there is any piece information that they should now about certain company, it will be already known to them; thus, they will boost their credit ratings and lower the interest rates. This piece of work can be of a value to both, creditors and shareholders; it is the first attempt to translate the analysts' following into a variable that gives an insight about the company's level of corporate governance and credit quality.

\section{References}

1. Alderson, M. and B. Betker. "Liquidation costs and capital structure." Journal of Financial Economics 39 (1995): 45-69

2. Allen, F. and Gale, D. (2000). "Financial Contagion," Journal of Political Economy, Vol. 108

(1), 1-33.

3. Defond, M. and J. Jiambalvo. "Debt covenant violation and manipulation of accruals." Journal of Accounting and Economics 17 (1994): 145-176.

4. Bhojraj, S. and P. Sengupta, (2003), "Effect of corporate governance on bond ratings and yields: the role of institutional investors and the outside directors." The Journal of Business, 76, pp. 455-475.

5. Bhattacharya, N., H. Desai and K. Venkataraman (2008), "Earnings quality and information asymmetry: Evidence from trading costs," Working Paper, Edwin L. Cox School of Business, Southern Methodist University.

6. Bhattacharya, N., F. Ecker, P. Olsson and K. Schipper (2009), "Direct and mediated associations among earnings quality, information asymmetry and the cost of equity," Working Paper, Fuqua School of Business, Duke University.

7. Boubakri, N., and Ghouma, H., (2007), "Creditor rights protection, ultimate ownership and the debt financing costs and ratings: international evidence." Working Paper, School of Business, Al Akhawayn university.

8. Brennan, M., T. Chordia and A. Subrahmanyam (1998), "Alternative factor specifications, security characteristics and the cross-section of 
expected stock returns," Journal of Financial Economics, 49, 345-373.

9. Gilson, S. C. "Transactions costs and capital structure choice: evidence from financially distressed firms." Journal of Finance 52 (1997): 161-196.

10.Hamdi B. Hatem G. and El-Mehdi A. (2014) "Auditor choice and corporate bond ratings: international evidence" International Journal of Economics and Finance; Vol. 6, No. 1; 2014.

11.Satt, H. (2014) "The Impact of positive cash operating activities on the cost of debt: international evidence" European Journal of Contemporary Economics and Management. Vol, NO 2.

12.Satt, H. (2015) "The Impact of positive cash operating activities on bonds' pricing: international evidence" Journal of Corporate and Ownership Control 12.4 (2015): 708-717

13.Holmström, B. and Tirole, J. (2001). "LAPM: a liquidity-based asset pricing model", The Journal of Finance, Vol. 56 (5), 1837-1867.

14.Kasznik, R. (1999), "On the association between voluntary disclosure and earnings management," Journal of Accounting Research, 37 (1999), 57-81.

15.Kim, O. and R. E. Verrecchia (1991), "Market reaction to anticipated announcements," Journal of Financial Economics, 30, 273-309.

16.Kim, O. and R. E. Verrecchia (1994), "Market liquidity and volume around earnings announcements," Journal of Accounting and Economics, 17, 41-67. 17.Klock, M., S. Mansi and W. Maxwell, (2005), "Does corporate governance matter to bondholders." Journal of
Financial and Quantitative Analysis, 40, 4, pp. 693-720.

18.Kubota, K. and H. Takehara (2009), "Information based trade, the PIN variable, and portfolio style differences: Evidence from Tokyo stock exchange firms," PacificBasin Finance Journal, 17, 319-337.

19.0mar Farooq and Harit Satt. "Does analyst following improve firm performance? evidence from the MENA region" Journal of corporate and Ownership control 11.2 (2014): 145-154.

20.Sengupta, P., (1998), “Corporate disclosure quality and the cost of debt." The Accounting Review, 73, pp. 459-474.

21.Shleifer, A. and Vishny, R., (1997), “A survey of corporate governance". Journal of Finance, vol. 52, issue 2

22.White, H. "A heteroscedasticityconsistent covariance matrix and a direct test heteroscedasticity." Econometrica 48 (1980): 817-838.

23.Willenborg, M. "Empirical Ana lysis of the economic demand for auditing in the initial public offering market." Journal of Accounting Research 37 (1999): 225-238

\section{Note}

1 The Institutional Brokers' Estimate System (I/B/E/S) is a database owned by Thomson Financials and provides data on analyst activities, such as earnings forecasts and stock recommendations issued by them. The I/B/E/S provides a data entry for each forecast and each recommendation announcement by each analyst whose brokerage house contributes to the database. Each observation in the file represents the issuance of a forecast or a recommendation by a particular brokerage house for a specific firm. For instance, one observation would be a forecast or a recommendation by Brokerage House ABC regarding Firm XYZ. 